NBER WORKING PAPER SERIES

\title{
LABOUR MARKET INSTITUTIONS WITHOUT BLINDERS: THE DEBATE OVER FLEXIBILITY AND LABOUR MARKET PERFORMANCE
}

\author{
Richard B. Freeman \\ Working Paper 11286 \\ http://www.nber.org/papers/w11286 \\ NATIONAL BUREAU OF ECONOMIC RESEARCH \\ 1050 Massachusetts Avenue \\ Cambridge, MA 02138 \\ April 2005
}

The views expressed herein are those of the author(s) and do not necessarily reflect the views of the National Bureau of Economic Research.

C2005 by Richard B. Freeman. All rights reserved. Short sections of text, not to exceed two paragraphs, may be quoted without explicit permission provided that full credit, including $\odot$ notice, is given to the source. 
Labour Market Institutions Without Blinders: The Debate over Flexibility and Labour Market Performance

Richard B. Freeman

NBER Working Paper No. 11286

April 2005

JEL No. J0

\section{ABSTRACT}

The debate over the influence of labour market flexibility on performance is unlikely to be settled by additional studies using aggregate data and making cross-country comparisons. While this approach holds little promise, micro-analysis of workers and firms and increased use of experimental methods represent a path forward. Steps along this path could help end the current 'lawyer's case' empiricism in which priors dominate evidence.

Richard B. Freeman

NBER

1050 Massachusetts Avenue

Cambridge, MA 02138

and Harvard University

freeman@nber.org 
In the thrilling days of yesteryear, economists believed that the key to economic performance was macro-economic policy. Monetarists argued that appropriate monetary policies were the magic bullet for price stability and curbing the business cycle. Keynesians favored fiscal policy: deficits to speed economic recovery and surpluses to reduce inflationary pressures.

Today, there is a new orthodoxy that makes the deregulation of labour market institutions and increased employment and wage flexibility in the labour market the keys to economic success. International agencies, such as the OECD and IMF, and many economists blame unemployment and sluggish economic growth on unions and state regulations of pay and employment that purportedly reduce market flexibility. They recommend that governments weaken labour market institutions in favor of market driven solutions. They call for reductions in the pay of low wage workers to create additional demand for them and tax breaks for the highly paid to induce them to work more or harder.

At the same time, there are substantive and growing objections to the evidentiary base on which the new orthodoxy rests. Analysts critical of the claim that deregulating labour markets and weakening trade unions will cure unemployment and spur economic growth argue that the models that justify these policies are non-robust and ill-specified, more sawdust than hard wood. As the criticisms have mounted, many international organizations have backed away from their condemnation of labour instutions and now express more nuanced views about the economic effects of labour market institutions than they did a decade or so earlier. But others hold firmly to the view that, to paraphrase former President Clinton, "it's the labour institutions, stupid". Why, despite over a decade of empirical analysis, have economists failed to reach consensus on the effect of labour institutions on aggregate economic problems and on the potential for deregulation to improve outcomes? Is the problem with data? Is the problem with 
the way economists have examined the data? How might we advance more rapidly our knowledge about labour institutions to answer the critical questions?

This paper argues that there are two reasons for inconclusive debate over the claim that labour institutions impair aggregate performance. ${ }^{1}$ The first reason is that many adherents to the claim hold strong priors that labour markets operate nearly perfectly in the absence of institutions and let their priors dictate their modeling choices and interpretation of empirical results. The second reason is that the cross-country aggregate data at issue is weak - too weak to decisively reject strong prior views or to convince those with weaker priors. Barring a Great Depression level collapse of the US or EU economies, I cannot imagine the aggregate evidence being so clear as to overwhelm strong priors.

Progress in economics comes, however, not from maintaining priors in the face of weak evidence but from obtaining new evidence and adjusting priors to new knowledge. To improve our understanding of how labour institutions operate, and move the debate to more productive terrain, I propose a two-part research strategy: 1) empirical analyses of firms, workers, unions and other groups in micro settings that resemble the interactions of institutions in the macroeconomy; and 2) development of more sophisticated priors through artificial agent simulations of markets where institutions can have positive as well as negative effects on outcomes. The combination of micro evidence and of simulations of how institutions operate offers a way around the inconclusive aggregate data that has made the debate over flexibility and labour market performance so unsatisfying .

\section{The orthodox view: "It's labour institutions, stupid."}

The 1994 Jobs Study of the OECD (OECD 1994a, 1994b) brought to the center of policy

${ }^{1}$ This paper deals with the debate over institutions in developed economies. For an analysis of the debate with regard to the developing countries, see Freeman (1993). 
debate the claim that labour institutions were the primary cause of unemployment in advanced countries. The Jobs Study listed ten recommendations to reduce unemployment and improve economic performance in the OECD. Five of the factors were boiler plate platitudes: good macro-economic policy; enhanced technological knowledge; elimination of impediments to creation of enterprises; improved education and training; enhanced product market competition. Four recommendations called for labor market deregulation: increased flexibility of working time; making wage and labour costs more flexible by removing restrictions; reforming employment security provisions; and reforming unemployment and related benefit systems. The last recommendation endorsed active labour market policies - training programs, job-finding assistance to workers, subsidies to employers to hire long-term unemployed or disabled workers, and special programs for youths leaving school. ${ }^{2}$ Most analysts and policy-makers interpreted the Jobs Study as blaming the economic problems of advanced Europe on inflexible regulated labour markets.

Nearly a decade after the Jobs Study, the IMF published an article in its World Economic Outlook that predicted that unemployment in Europe would fall massively below US levels if European countries deregulated their labor market and product markets:

"labor reforms could produce output gains of about 5 percent and a fall in the unemployment rate of about 3 percentage points. ... those benefits could be doubled by simultaneous efforts to increase competition in the product market."3

high unemployment is largely structural in nature - and thereby potentially affected by institutions - rather than cyclical (and therefore determined by the business cycle and macroeconomic policies). (Enact the reforms and) ... unemployment could fall by about $6 \frac{1}{2}$ percentage points" 4

\footnotetext{
${ }^{2}$ John Martin

${ }^{3}$ IMF, 2003, chapter 4, p 129

${ }^{4}$ IMF, 2003, chapter 4, p 131
} 
"when labor markets are more competitive, the economy reacts more quickly and smoothly to changes in interest rates. This facilitates the task of the monetary authorities; in particular, smaller changes in interest rates — and therefore output — are necessary to stabilize inflation in the face of shocks.". 5

The belief that labour institutions impede economic efficiency is not new to the IMF and other international financial institutions (IFIs). The Fund published a similar analysis of European unemployment problems in 1999, albeit without such bold predictions about the huge reduction in unemployment that "reforms" would generate. In their effort to help developing countries deal with balance of payments and fiscal deficit problems, both the Fund and the World Bank have long feared that labour institutions will undermine the macro-economic stabilization policies and structural adjustment programs they recommend. In a balance of payments crisis, a country must shift resources from non-traded goods to traded goods. This usually requires a currency devaluation, which lowers the real wage. Since traded goods sectors tend to be capital intensive, moreover, the reallocation of resources is also likely to increase returns to capital relative to the returns to labor. Similarly, in a fiscal crisis, governments must raise taxes and/or reduce public spending, which lowers real wages and redistributes income from the poor to the wealthy. Since the recommended policies harm labour, at least in the short run, the IFIs naturally worry that unions and other labour institutions, which seek to protect the economic well-being of workers, will oppose the policies. The IFIs view labor insitutions as potential "flies in the ointment" of the adjustments needed to restore economic health to sick economies.

This perspective has led IMF-associated economists to stress the dangers of insufficient labour market flexibility in economic crises even when those crises arise from problems far removed from the labour market. Commenting on the 2002 economic collapse of the Fund's

${ }^{5}$ IMF, 2003, chapter 4, p 129 
once poster economy, Argentina, Michael Mussa, former chief economist at the IMF wrote:

"If Argentina had a more flexible economic system, especially in its labor markets, its economy would have been more able to adapt to the rigors of the convertibility plan, unemployment would have been lower, growth would have been stronger, fiscal deficits would have been smaller, and interest rates would have been lower"

At an NBER conference, Anne Krueger, then first deputy managing director, expressed a similar view, blaming Argentina's problems on

“... two factors ... weak fiscal policy and mounting overvaluation, the latter reflecting relatively high inflation, a stronger dollar, and insufficient domestic flexibility (for example, in the labor market). The last point is especially important - under a firmly fixed exchange, you need other sources of adjustment to maintain competitiveness."7

While neither IMF expert called for Argentina to weaken its unions, lower minimum wages, lessen employment protection laws, cut unemployment benefits, etc., those are the orthodox ways to make labor markets more flexible.

\section{The other side: Innocent till Proven Guilty:}

On the other side are economists and international agencies who see labour market institutions as a way of enhancing economic adjustments and avoiding macro crises. The Nordic (Rehn-Meidner) Model of the open macro-economy posits that peak level unions and employers' associations negotiate changes in wages that are roughly equal to productivity growth in traded goods sectors and changes in world prices, so as to maintain fixed exchange rates (Aukrust; Henry Milner and Eskil Wadensjö). The assumption is that national bargainers take account of macro-economic facts, while local labour markets would produce inflationary wage changes in periods of full employment. Reflecting a similar perspective, Mancur Olson has argued that centralized collective bargaining in small open Nordic economies works because all-

${ }^{6}$ Mussa, 2002, p. 9 The italics are mine.

${ }^{7}$ Anne Krueger, 2002, The italics are mine. 
encompassing "peak" union organizations internalize the negative externalities that arise in wage-bargaining at the firm or industry level. In fact, there is evidence that industry labour markets in Nordic countries operate closer to the competitive ideal than industry labour markets in the market-driven US. In the US changes in sectoral prices and productivity affect sectoral wages, contrary to the standard model of competitive wage setting ${ }^{8}$ whereas in the Nordic countries institutionally determined wages assure that changes in sectoral prices and productivity have little impact on sectoral wages (Holmlund and Zetterberg, 1991).

The international agency responsible for labour issues, the ILO, also

"takes issue with the view that labour market rigidity has been the major cause of unemployment and that greater labour market flexibility is the solution ... jobless rates appear to have risen independently of levels of labour market regulations ...trade union power was reduced in many countries, together with unemployment benefits and in some cases minimum wages, producing little if any positive employment effect." (www.jobsletter.org.nz/jbl05210.htm).

The ILO argues to the contrary - that economic systems based on labor-management discussions can improve aggregate efficiency: "Successful social dialogue structures and processes have the potential to resolve important economic and social issues, encourage good governance, advance social and industrial peace and stability and boost economic progress." The ILO does not root its positive attitude toward social dialogue in neo-classical economics, but the notion that negotiations can lead to efficient outcomes is consistent with Ronald Coase's analysis of transactions costs. The Coase theorem holds that regardless of the distribution of property rights, bargaining should produce an optimal allocation of resources as long as transactions costs are low. Labour institutions could redistribute income toward workers without harming economic efficiency.

8 This is what one would expect in an ideal competitive economy, where industry shocks alter employment but not wages. See Council of Economic Advisors, 1962 and Salter, for classic statements of this principle. 
In the 1980s and early 1990s the World Bank looked askance at labour institutions: "Labor market policies - minimum wages, job security regulations, and social security - are usually intended to raise welfare or reduce exploitation. But they actually work to raise the cost of labor in the formal sector and reduce labor demand ... and thus (depress) labor incomes where most of the poor are found." (World Bank, 1990b, p 63). But in its 1995 World Development Report the Bank gave a more balanced view. It wrote about "how should governments intervene in labor markets", (WDR, 1995, p 69) not why governments should not intervene. The WDR noted that "It is possible to identify the conditions and policies under which free trade unions can advance rather than impede development" (WDR, 1995, p 86 ). By 2003 the Bank had deviated even furthur from its traditional perspective. It released the book Unions and Collective Bargaining: Economic Effects in a Global Environment under the headline "Economies Perform Better In Coordinated Labor Markets". This volume reported that "Workers who belong to trade unions earn higher wages, work fewer hours, receive more training, and have longer job tenure on average, than their non-unionized counterparts .... On the other hand, temporary layoffs can be more frequent in unionized firms. At the macroeconomic level, high unionization rates lead to lower inequality of earnings and can improve economic performance (in the form of lower unemployment and inflation, higher productivity and speedier adjustment to shocks)" (World Bank Group, 2003).

The InterAmerican Development Bank has a similar view. In 2003 it explicitly rejected the deregulation solution and called for institutions to help markets work better: "Labor regulations are not cost-free, but deregulation is not the answer.... Unions are neither the sand in the wheels of the labor market nor the solution to low wages.... better labor market performance is compatible with lower earnings inequality ... The new agenda requires a strengthened labor 
authority and a complex network of public and private institutions" (InterAmerican Development Bank, 2003 pp 7-8).

In short, while the position that labor market institutions are a major cause of unemployment and related aggregate economic problems has considerable adherents, there is a substantial and growing number of economists and international agencies who take exception to that view.

\section{What the Data Shows}

The natural way to resolve the debate about how labour institutions affect economies is to examine data on economic outcomes in the presence and absence of the institutions. At this writing, there have been dozens of studies that compare aggregate outcomes between countries with or without various institutions and in the same country before and after it changes an institutional arrangement.

The OECD has been a major contributor to the research. Its 1994 Jobs Study report was accompanied by two volumes of supporting research and was followed by numerous studies and reviews of studies, many given in the OECD's annual Employment Outlook. The OECD has provided new and valuable measures of employment protection legislation and of replacement rates in unemployment benefit systems and measures of product market institutions as well as of labour market institutions. In addition, Steve Nickell (1997), with various co-authors, and Layard, Nickell, and Jackman (1994) have contributed significantly to the case that labour markets are the root cause of Europe's unemployment. Reading these studies, most of which confidently proclaim that the data prove that institutions are indeed the problem, one could readily end up believing that there was overwhelming scientific support that European labour institutions are guilty as charged of having caused joblessness and slow economic growth. 
But these analyses are akin to a prosecutor's case in a trial. They give the evidence that suggests the institutions are guilty but do not reflect on the weaknesses of that evidence. To reach a verdict, it is necessary as well to see the arguments by analysts who take the other side of the debate - the defense attorneys, as it were. These researchers give a different reading of what the data shows and, most important, of the robustness of the case against labor institutions. ${ }^{9}$ In a volume devoted to debunking the Jobs Study claims, Baker, Glyn, Howell, and Schmidt (2004) document that the findings in several time series models that find that institutions adversely affect aggregate outcomes are not robust. The estimated coefficients on labour institutions disappear or becomes statistically insignificant when the researchers make modest changes in the measures of instititutions, countries covered, and time periods of analysis. Models that cover more years, countries, and measures than earlier studies "provide little support for those who advocate comprehensive deregulation of OECD labor markets" (p 106). Baker et al conclude that there is a "yawning gap between the confidence with which the case for labor market deregulation has been asserted and the evidence that the regulating institutions are the culprits" (p 198). Blanchflower (2001) tells a similar story, noting "only a weak positive relation in the OECD between unemployment and benefits (p 390) and "no support (from a 1999 OECD report) ... for the belief that unions, benefits, the tax wedge, ALMP spending or earnings dispersion influence unemployment ... contrary to the claims made in Layard et al, which appear to be based on misspecified cross-country unemployment regressions (p 392)”.

${ }^{9}$ Nickell and Bell, 1996 show that EU-US employment gaps are as large among skilled as among less skilled workers. Card, Kramarz and Lemieux (1994) and Freeman and Schettkat, (2001) find little relation between employment and labor costs of workers by industry or occupation across countries. Increased hours worked in the US among the educated and women, whose wages rose relative to the US average, also runs counter to the rigidity story (Freeman, 1995). Evidence that changes in the US minimum had negligible employment effects imply that low wages did not cause high employment (Card and Krueger 1997) 
Why are supporters of the new orthodoxy so convinced that their analysis definitively convicts labour institutions while critics find inconclusive results in the same data?

Blanchard and Wolfers suggest that one reason is a form of regression-mongering, in which the models used to make the case against institutions "are in part the result of economic Darwinism ... measures ... constructed ex post facto by researchers who were not unaware of unemployment developments" (Blanchard and Wolfer, 2002, p 18). As an example of this form of analysis, Blanchflower notes that some models include country dummy variables that effectively remove observations that fail to fit the orthodox model. If Spain (or Ireland, or any country) had drastically a different employment experience than measures of labour institutions suggest they should have, analysts with strong priors can invariably find enough idiosyncracies about that country to convince themselves that its observations should be treated differently than those of other countries.

In sum, both sides of the debate over institutions have operated as lawyers in a trial, driven by a strong commitment to their client (priors). Adherents to the new orthodox view search the data for specifications/measures that support their priors, while barely noticing evidence that goes against them. If results are inconsistent with the priors, they assume that something is wrong with their empirical specification or measures, rather than question the validity of their case. If results fit their priors, they rarely look further to find weaknesses. On the other side, critics of the case that labor institutions are the root cause of economic problems act as defense attorneys. They see their job as finding specifications and measures that make the institutions innocent of the alleged crime of causing unemployment or other economic problems. To the extent that the burden of proof is on the prosecutor, the defense team has an easier job. They do not have to come up with another suspect, which is hard, but have only to demonstrate 
that the data are more ambiguous than the prosecutor claims.

At this writing, the critics of the new orthodoxy have done this with sufficient success to impel even the OECD to retreat from its strong Jobs Study claim to a more equivocal position about the impact of institutions on outcomes. ${ }^{10}$ The 2004 OECD Employment Outlook admitted that "the evidence of the role played by EPL (employment protection legislation) on aggregate employment and unemployment rates remains mixed" (p 81); and expressed concern that the temporary contracts that replaced permanent jobs in some countries (such as Spain) produced labour market duality between those with permanent contracts and those with temporary contracts and job insecurity that were themselves a problem. The Outlook argued for "the plausibility of the Jobs Strategy diagnosis that excessively high aggregate wages and/or wage compression have been impediments" to jobs, while admitting that "this evidence is somewhat fragile". With respect to unionism, it accepted that the effect of collective bargaining "appears to be contingent upon other institutional and policy factors that need to be clarified to provide robust policy advice" (p. 165).

While proponents and opponents of the case against labour institutions disagree about the whether labour institutions are a significant contributor to unemployment and aggregate economic efficiency, it is important to recognize that they concur on one point: that labour institutions, particularly those associated with trade unions, reduce inequality of pay compared to pay in competitive markets. ${ }^{11}$ The evidence here is overwhelming. In countries like the US which decentralized labor markets set pay, dispersion of earnings is lower in unionized

\footnotetext{
${ }^{10}$ The evolving views of the OECD can be seen in various Employment Outlooks (1995, 1996, 1997, 1999).

${ }^{11}$ This is true for advanced countries. The situation is more ambiguous in developing countries since unions do not represent workers in the informal sector and rarely represent rural workers, who are paid less than those in the modern sector.
} 
workplaces than in nonunion workplaces; dispersion of pay falls for the same workers when they move from nonunion to union settings, and increases when they move in the opposite direction. Across countries, dispersion of pay tends to be lower in countries with high rates of collective bargaining coverage than in countries with low rates of collective bargaining. Over time, moreover, dispersion decreases in countries when institutions play a greater role in pay setting and increases when institutional pay setting gets weaker. For example, when Italy used the Scala Mobile to set pay, inequality fell rapidly whereas when it scrapped that form of national pay bargaining, inequality began to rise. ${ }^{12}$

In short, priors aside, the best summary of the data - what we really know - is that labour institutions reduce earnings inequality but that they have no clear relation to other aggregate outcomes, such as unemployment. From the perspective of the evidence, the claim that "it's labour institutions, stupid" is an interpretation, perhaps right, perhaps wrong, of the link between institutions and aggregate economic problems. That institutions affect distribution but do not affect aggregate efficiency is consistent with a Coase-theorem interpretation of how institutions operate, though it is far from conclusive..$^{13}$

\section{The Role of Strong Priors in the Case Against Labor Institutions}

Despite the lack of robust evidence, many economists and policy-makers continue to strongly defend the orthodox view that institutions are the root cause of economic problems. In the January 2005 Economic Journal Nickell, Nunziata, and Ochel reitorated the claim that "the broad movements in unemployment in the OECD can be explained by shifts in labour market institutions" (p 1) ... without responding to the evidence given by critics of that view. And the

\footnotetext{
${ }^{12}$ Erickson and Ichino, 1995; Manacorda, 2004
}

${ }^{13}$ Patterns in strikes run counter to a Coase theorem interpretation. If management and workers lose from strikes, they should come to an agreement without strikes or lockouts. 
IMF published the analysis cited earlier (IMF, 2003) and which I will consider in depth shortly also without responding to critical commentary about the robustness of results.

What explains strong adherence to a claim whose empirical support is "fragile", "mixed", "contingent on factors that need to be clarified", and so on?

The best interpretation I can give is that these economists come to the problem of explaining unemployment with the prior that markets work well absent interventions, and thus that the right place to look for causes of problems is at institutions that may impede the operation of the markets. ${ }^{14}$ They have fairly tight bands around this prior, so that it dominates weak evidence, and thus produces posteriors close to the priors, as in standard Bayesian inference.

The April 2003 article in the IMF's World Economic Outlook quoted earlier provides an example of such prior-driven analysis. As noted, this article predicted that "reforms" that would make European labour markets more like those in the US would reduce EU unemployment from $8.0 \%$ to $5.0 \%$ and raise GDP by 5 percent, while a combination of labour and product market reforms would reduce EU unemployment by 6.5 points to $1.5 \%$ !

Analysts with weaker priors might have noticed that the magnitude of these effects border on the impossible. In 2003 many EU countries had unemployment rates below 6.5\% -- Austria, Denmark, Eire, Netherlands, Luxembourg, Portugal, Sweden, and the United Kingdom (as well as Norway outside the EU), so the 6.5 point drop would put them into negative unemployment terrain. Since this cannot occur, rates would have to fall by more than 6.5 points in other

${ }^{14}$ The Spring 2004 German IFO institute economics magazine CESifo Forum was devoted to European labour markets. Many economists favoured some aspects of the orthodox view while one (me) argued that European labour markets were not "as bad as all that" (Freeman, 2004). My argument was that no real world market looks good when compared to the ideal competitive market, but that such a comparison was misleading since no real world market performs in accord with the competitive ideal; and that it was this comparison of European labour markets with the ideal that led many analysts astray. 
countries. Analysts with weaker priors might have noticed that the country with nominally the most flexible institutions, the US, did not have anything close to the predicted $1.5 \%$ rate of unemployment. In 2003 the US unemployment rate was 6.0\%. That the EU would have onefourth the unemployment rate that the US had if the EU only had flexible US institutions seems prima facie nonsense. If the US couldn't attain a $1.5 \%$ unemployment rate with these flexible institutions or even the 5.0\% unemployment rate predicted for European countries if they adopted US style labour practices, why should European countries do so well?

The excessive claim does not come from erroneous empirical work. The most rigorous analysis in the article shows nothing like these effects. This analysis estimates a vector of “Institution-Adjusted Unemployment Rates" for OECD countries - unemployment rates minus the estimated impact of institutions on unemployment. Graphs in the article show that these rates closely track actual changes in unemployment rates, and the article informs the reader that this means that "Institutions ...hardly account for the growing trend observed in most European countries and the dramatic fall in U.S. unemployment in the 1990s" (my italics). ${ }^{15}$ In particular, the article stressed that Germany had broadly unchanged institutions while unemployment rose by about 6 percentage points. No change in institutions and higher unemployment - just the sort of conclusion one might have expected from one of the critics of the orthodox position. But, despite this finding, the article's message was that weakening institutions would reduce unemployment to $1.5 \%$. How could they reach such a conclusion from such data?

The analysts tell us: by ignoring the longitudinal evidence (which most empiricists would regard as providing a stronger and more valid test of any claim) in favor of cross section regressions that showed that institutions “... alone explain a good deal of the cross-country

${ }^{15}$ IMF, April 2003, figure 4.4, p 134. 
differences in unemployment rates". In the context of US-EU differences, this is a nearly circular argument: the US has different institutions and lower unemployment than Europe, so those institutions must explain the difference in unemployment. That the cross section analysis predicted that Europe's rate of unemployment would fall by incredible amounts to 1/4th the US's rate of unemployment should have been a red flag that even here something was amiss - be it misspecification, omitted variable bias, what have you, of the sort that longitudinal analyses are designed to reduce, if not eliminate. But the strong prior that European unemployment was due to labour institutions overwhelmed the empirics and interpretation thereof. The prosecuting attorney was committed to argue for conviction no matter what.

\section{Configurations and evidence}

Priors aside, the problem of determining how institutions affect outcomes is difficult.

One difficulty is the large number of possible configurations of institutions relative to the number of cross-country observations on which to assess their impact on outcomes. ${ }^{16}$ By configurations I mean combinations of institutional arrangements, such as union density, collective bargaining coverage, centralization of bargaining, employment protection laws, government regulation of wages, affirmative action policies, etc. Consider the problem of analysing 4 institutions, all coded as $0 / 1$ so that a country has/does not have a given institution, and with institutions measured so that having one implies less reliance on decentralized markets. In an experimental design to assess the impact of institutions, we would look at the outcomes associated with the $32\left(=2^{4}\right)$ logically possible configurations of institutions. ${ }^{17}$ The orthodox

${ }^{16}$ Charles Ragin (1987) has done the most to analyze the problem of inferring relations from configurations.

${ }^{17}$ If we used a high/medium/low categorization, we would have $81 \quad\left(=3^{4}\right)$ possible configurations. 
hypothesis would be that the configuration with four 0s would give the best outcome - the lowest unemployment rate. The alternative hypothesis that centralized bargaining works best would be that the configuration with four 1's would give the best outcome. In between are a diverse set of possibilities.

The social world does not provide the evidence needed to assess all of the possibilities. Invariably there are no observations on some configurations, some of which may be impossible to fit together, but others of which may be unobservable for some less compelling reason - such as historical circumstance. There will also be some combinations for which the observation is a single country, which makes it indistinguishable from anything else unique about that country, and thus possibly meaningless for assessing how the combination might work in some other country. With only 30 or so advanced countries, highly correlated outcomes, and infrequent changes in institutions, the number of configurations can easily exceed the number of independent data points. ${ }^{18}$

To deal with the problem of excessive configurations, analysts of labour institutions have aggregated arrangements into simpler categories: "neo-corporatist" economies vs "liberal" economies, and so on. But there is no uniform agreement about these groupings. For example, Japan combines company level unionism and profits related bonuses with a strong employer federation, the Shunto offensive, and a sense of national unity. Is this neo-corporatist or liberal, or does Japan merit its own categorization? As long as countries have many institutions that differ in many ways, researchers risk forming classifications or groupings that support their

${ }^{18}$ The highly correlated outcomes implies that having higher frequency data cannot resolve the problem - you don't learn any more by having monthly unemployment rates than from yearly unemployment rates. In developing countries, the Easterly, Kremer, Pritchett, and Summers' finding that growth rates are not highly correlated creates a different problem in assessing how institutions or policies affect outcomes. 
priors rather than that test those views.

Another difficulty in analysing how institutions affect outcomes is that unlike Gertrude Stein's " a rose is a rose is a rose", institutions change over time as their members and leaders learn from experience. Unions, government regulators, and employer federations do not respond in the same way to the same stimula regardless of past events any more than does any other economic agent. As cases in point, consider the way the British and German unions behaved in the 1970s to the way they acted in the 1990s. In the seventies, the British unions were troglodytes, opposed to seemingly rational economic thought and responsibility toward the UK economy. German unions were widely praised as responsible economic agents. In the 1990s the British unions were the modernizers, with the TUC endorsing "value added" unionism on the notion that only if unions could add value to the performance of firms would they be able to improve the well-being of workers. By contrast, the German unions seemed incapable of adjusting to the economic realities of post-unification Germany and globalization. Recognizing that unions learn from the past, one would not want to assume that unions would respond to some future inflationary shock as they did to the 1970s inflation.

\section{Doing better}

If excessively strong priors, configurations too numerous or complex for aggregate data, and changes in institutional behaviour limit our ability to bring the debate about how labour markets affect aggregate outcomes to closure, what can we do to increase our understanding of those institutions?

My proposed strategy has two parts. First, to supplement priors based on perfect markets with priors based on experimental economics lab findings and artificial agent simulations of markets which allow institutions to have positive as well as negative effects on outcomes. 
Second, to examine data on how firms, workers, unions and other groups operate in micro settings that resemble the macro-economic institutional settings.

\section{developing more realistic priors}

The prior that labor markets work perfectly absent institutional interventions comes from standard models of how rational optimizing agents interact in competitive markets. ${ }^{19}$ Although economics has theories that deal with other markets - monopsony theory being perhaps the most prominent in labour analysis (Manning, 2005) - most economists downplay their importance and hold the prior that markets operate according to the competitive model unless proven otherwise. As a first approximation, this seems sensible, but once empirical evidence shows that the perfect market model is incomplete, it is necessary to do more than search for impediments to perfection. Analyzing the markets which most closely fit the theoretic ideal, financial markets, economists have found it necessary to go beyond the first approximation "efficient market model". Indeed, the anomolies in financial markets, which can generate huge economic problems, have spawned an entire field, behavioral finance. While it is always dangerous to argue by analogy, I am willing to make such an argument here. If it's necessary to develop more realistic priors about behavior in finance, where all that matters is money, then surely it's necessary to do so in labor, where market participants are concerned with much more than monetary considerations.

To develop more realistic priors about how people and institutions operate in aggregate economies, we can make greater use of two modes of analysis. The first mode are laboratory experiments, which provide insight into individual behavior and the way individuals connect in markets. Experimental economics (see Kagel and Roth, 1995) has generated findings about behaviour in diverse situations - the ultimatum game, the dictator game, the prisoners dilemma

${ }^{19}$ Economists, like the general public, also derive priors from "anecdotal evidence" - ie the events that we personally experience or observe others experiencing. 
game, and public goods games, that have implications for labour institutions. Experimental economics has also generated findings about the conditions under which supply and demand clear markets, and the conditions under which they do not. While the jump from laboratory experiments to actual institutions is a large one, knowledge of what experimental economics has found should help us form better priors about what to expect from labour institutions.

The second tool are simulations based on artificial agent modeling. This form of modeling can help us develop priors about the interaction among decision units. The Sante Fe Stock market model (Le Baron, 2002), for example, shows how competing strategies adopted by agents with bounded rationality can interact to produce swings in stock market values that more resemble the actual swings than the random fluctuations in any efficient market model. Models of labour economic institutions have focused on issues relating to the matching of firms and workers (Neugart, 2004; Pingle and Tesfatsion, 2003) but they could not also examine other institutions or issues - for instance the high dispersion of wages in labour markets. Al Roth and co-workers $(1999,2000)$ have shown the value of combining modeling with the design of new institutional forms for specific labor markets. These models provide powerful priors for what to expect from actual institutions or changes in institutions.

\section{Using micro data}

Priors help interpret evidence, but ultimately it is evidence that ends scientific debate. If you accept my claim that the aggregate evidence is unlikely to be definitive in bringing closure to the labour institution debate, then we should look for more micro evidence. Studies of firms, whose organization is sufficiently complicated to provide insight into interactions of institutions at a higher level, would seem to offer the most promising area for research. There are lots of firms and lots of changes in labor practices among them, so there is no lack of data. To judge 
whether formal labour market rules produce worse employment outcomes, as claimed by orthodox analysts, one could contrast employment between firms with more or less rigid internal rules. When Martin Weitzman (1984) hypothesized that profit-sharing could reduce unemployment and maintain low inflation by creating a permanent excess labor demand, labour economists analyzed the employment pattern of firms with and without profit-sharing (Kruse, 1993) and found that the data was generally supportive of the hypotheses. While there are problems with generalizing from micro analysis to the aggregate economy, there is still much we can learn about how labour institutions operate from micro data. Indeed, the most convincing evidence that some regulations affect unemployment adversely comes from micro studies that show that longer durations of unemployment benefits generate longer spells of unemployment. These estimates are much smaller than those obtained in some cross-country regressions, but they are robust and driven by the data rather than strong priors and particular model specifications. More can be learned from narrower investigations of hypotheses than from the sweeping claims based on weak aggregative data.

\section{Conclusion}

I draw three lessons from the debate over the link between labour instititutions and aggregate outcomes.

First, that the debate cannot be resolved by analysis of the aggregate data in question. The data do not scream out loudly and clearly "it's labour institutions, stupid," as the new orthodoxy initially claimed, nor does the data say "that's impossible". Rather, the data mumble omething akin to "I don't know ... don't ask me ... maybe ... your guess is as good as mine."

Second, that researchers should beware the power of priors, particularly their own, in analysing weak aggregate data. Strong priors can be blinders to knowledge, and can lead to 
excessive "lawyers" case" empirical analysis, which will eventually be rebutted.

Third, there is a road to improved knowledge. It is through developing more sophisticated priors about how people behave in institutional settings and how institutions interact in markets on the one side; and through analysis of the response of workers and firms to particular institutional settings in micro settings. It is not by continued regression mongering of weak cross country data . 


\section{References}

Aukrust, O. 1977. "Inflation in the Open Economy: A Norwegian Model', in L.B. Krause and W.S. Salent (eds.): Worldwide Inflation; Theory and Recent Experience. Washington DC: Brookings Institution.

Baker, D, Andrew Glyn, David Howell, and John Schmidt. 2004. "Labor Market Institutions and Unemployment" in D. Howell (ed.) Questioning Liberalization: Unemployment, Labor Markets, and the Welfare State, Oxford, UK: Oxford University Press.

Blanchard, Olivier and Justin Wolfers. 2000. "Shocks and Institutions and the Rise of European Unemployment: The Aggregate Evidence," Economic Journal 110(1): 1-33.

Blanchflower, David G. 2001. "Unemployment, Well-Being, and Wage Curves in Eastern and Central Europe," Journal of the Japanese and International Economies 15, pp 364-402.

Card, D., F. Kramarz, and T. Lemieux. 1994. "Changes in the relative structure of wages and employment: A comparison of the United States, Canada and France," Princeton N.J.: Princeton University Manuscript (December).

Card, D.and A. B.Krueger 1997. Myth and Measurement, Princeton, NJ: Princeton University Press.

Council of Economic Advisors. 1962. Economic Report of the President. Washington, DC: Government Printing Office.

Easterly, William, Michael Kremer, Lant Pritchett, and Lawrence H. Summers. 1993.

"Good Policy or Good Luck? Country Growth Performance and Temporary Shocks." Journal of Monetary Economics 32 (3): 459-83.

Erickson C and A. Ichino (1995), .Wage differentials in Italy: Market Forces, Institutions and Inflation., in Freeman R, Katz L (eds), Differences and Changes in Wage Structure, University of Chicago Press

Freeman, Richard B. 1993. "Labor Market Institutions and Policies: Help or Hindrance to Economic Development?" Proceedings of the World Bank Annual Conference on Development Economics 1992. Washington, DC: The World Bank.

\section{Focus: The European Labour Markets.}

Freeman, R.B. and R. Schettkat. 2001. 'Skill compression, wage differentials and employment: Germany versus the US', Oxford Economic Papers, 582-603.

Freeman, Richard B. 1995. "The Limits of Wage Flexibility to Curing Unemployment," Oxford Review of Economic Policy, 11(1) (Spring) pp 214-222. 
Holmlund, Bertil and Johnny Zetterberg. 1991. "Insider Effects in Wage Determination: Evidence from Five Countries," European Economic Review, July.

InterAmerican Development Bank. 2003. Good Jobs Wanted. Baltimore, MD: Johns Hopkins Press.

International Monetary Fund (IMF). 1999. "Chronic Unemployment in the Euro Area: Causes and Cures." Chapter 4 in World Economic Outlook (May). Washington, DC: IMF.

---------. 2003. “Unemployment andd Labor Market Institutions: Why Reforms Pay Off." Chapter 4 in World Economic Outlook (April). Washington, DC: IMF.

Kagel, John H. and Alvin E. Roth (eds). 1995. The Handbook of Experimental Economics. Princeton, NJ: Princeton University Press. Paperback edition, Fall 1997.

Krueger, Anne. 2002. "Crisis Prevention and Resolution: Lessons from Argentina

National Bureau Of Economic Research (NBER) Conference on "The Argentina Crisis"

Cambridge, July 17. http://www.imf.org/external/np/speeches/2002/071702.htm

Kruse, Douglas. 1993. Profit-Sharing Does it Make A Difference? Kalamazoo, MI: W.E. Upjohn Institute for Employment Research.

Layard, R., S. Nickell, and R. Jackman. 1994. The Unemployment Crisis. Oxford: Oxford University Press.

LeBaron, Blake. 2002. "Building the Santa Fe Artificial Stock Market," Working Paper, Brandeis University, June.

Manacorda, Marco Can the Scala Mobile Explain the Fall and Rise of Earnings Inequality in Italy? A Semiparametric Analysis, 1977-1993', Journal of Labor Economics, 2004, vol. 22, no. 3, 585-613.

Manning, Alan. 2005. Monopsony in Motion: Imperfect Competition in Labor Markets. Princeton, NJ: Princeton University Press.

Martin, J 1998 "What Works Among Active Labour Market Policies: Evidence from OECD Countries' Experiences" www.rba.gov.au/PublicationsAndResearch/Conferences/1998/ Martin.pdf

Milner, Henry and Eskil Wadensjö. 2001. Göösta Rehn, the Swedish Model and Labour Market PoliciesInternational and National Perspectives Ashgate.

Mussa, Michael. 2002. “Argentina and the Fund: From Triumph to Tragedy," Policy Analyses in International Economics 67 (July), Institute for International Economics.

Neugart, Michael. 2004. "Endogenous matching functions: an agent-based computational approach," Advances in Complex Systems, 7(2) 187-202.

Nickell, S. J. and B. Bell. 1996. "Changes in the Distribution of Wages and Unemployment in the OECD countries," American Economic Review, Papers and Proceedings, 86(5): 302-308. 
Nickell, Stephen., Luca Nunziata, and Wolfgang Ochel. 2005. "Unemployment in the OECD since the 1960s: What Do We Know?" The Economic Journal 115 (January) 1-27. Royal Economic Society.

Nickell, S. 1997. "Unemployment and Labor Market Rigidities: Europe versus North America." Journal of Economic Perspectives 11(3) (Summer): 55-74.

Olson, Mancur. 1990. How Bright Are the Northern Lights?: Some questions about Sweden (Crafoord lectures). Lund, Sweden: Institute of Economic Research, Lund University.

Organization for Economic Cooperation and Development (OECD). 1994. OECD Jobs Study, Evidence and Explanations, Part I: Labor Market Trends and Underlying Forces of Change. Paris: OECD.

---------. 1994. OECD Jobs Study, Evidence and Explanations, Part II: The Adjustment Potential of the Labor Market. Paris: OECD.

----------. 1995. OECD Jobs Study, Taxation, Employment, and Unemployment. Paris: OECD.

----------. 1996. OECD Employment Outlook. Paris: OECD.

--------. 1997. "Economic Performance and the Structure of Collective Bargaining." OECD Employment Outlook (July). Paris: OECD.

1999. Implementing the Jobs Study. Paris: OECD.

2002. OECD Employment Outlook. Paris: OECD.

----------. 2004. OECD Employment Outlook. Paris: OECD.

Pingle, Mark and Leigh Tesfatsion. 2003. "Evolution of Worker-Employer Networks and Behaviors Under Alternative Non-Employment Benefits: An Agent-Based Computational Study," Computing in Economics and Finance, 7, Society for Computational Economics.

Ragin, Charles. 1987. The Comparative Method. University of California Press.

Roth, A. E. and Elliott Peranson. 1999. The Redesign of the Matching Market for American Physicians: Some Engineering Aspects of Economic Design American Economic Review, 89(4) (September): 748780.

Roth, Alvin E. 2002. "The Economist as Engineer: Game Theory, Experimentation, and Computation as Tools for Design Economics," Fisher-Schultz Lecture, Econometrica, 70(4) (July): 1341-1378.

Salter, W.E.G. (1960) Productivity and Technical Change. Cambridge, UK: Cambridge University Press.

Weitzman, Martin L. 1984. The Share Economy: Conquering Stagflation. Cambridge, MA: Harvard University Press.

World Bank. 1995. World Development Report. Washington, DC: The World Bank.

World Bank. 1990. World Development Report 1990. New York: Oxford University Press.

World Bank 2003 news release. web.worldbank.org/WBSITE/EXTERNAL/NEWS/0, contentMDK:20091655 menuPK:34463 pagePK:34370 piPK:34424 theSitePK:4607,00.html 